\title{
Evaluation of Chemical Constituents and Antioxidant Activity of Coconut Water (Cocus nucifera L.) and Caffeic Acid in Cell Culture
}

\author{
JOÃO L.A. SANTOS ${ }^{1}$, VANDERSON S. BISPO ${ }^{1}$, ADRIANO B.C. FILHO ${ }^{1}$, \\ ISABELLA F.D. PINTO ${ }^{1}$, LUCAS S. DANTAS ${ }^{1}$, DAIANE F. VASCONCELOS ${ }^{1}$, FABÍULA F. ABREU ${ }^{1}$, \\ DANILO A. MELO ${ }^{1}$, ISAAC A. MATOS ${ }^{1}$, FLORÊNCIO P. FREITAS ${ }^{2}$, OSMAR F. GOMES $^{2}$, \\ MARISA H.G. MEDEIROS ${ }^{2}$ and HUMBERTO R. MATOS $^{1}$ \\ ${ }^{1}$ Departamento de Fisiologia, Universidade Federal de Sergipe, \\ Av. Marechal Rondon, s/n, 49100-000 São Cristóvão, SE, Brasil \\ ${ }^{2}$ Departamento de Bioquímica, Instituto de Química, Universidade de São Paulo, \\ Av. Prof. Lineu Prestes, 748, 05508-900 São Paulo, SP, Brasil \\ Manuscript received on June 18, 2012; accepted for publication on October 23, 2012
}

\begin{abstract}
Coconut water contains several uncharacterized substances and is widely used in the human consumption. In this paper we detected and quantified ascorbic acid and caffeic acid and total phenolics in several varieties of coconut using HPLS/MS/MS $(25.8 \pm 0.6 \mu \mathrm{g} / \mathrm{mL}$ and $1.078 \pm 0.013 \mu \mathrm{g} / \mathrm{mL}$ and $99.7 \mu \mathrm{g} / \mathrm{mL}$, respectively, in the green dwarf coconut water, or $10 \mathrm{mg}$ and $539 \mu \mathrm{g}$ and $39.8 \mathrm{mg}$ for units of coconut consumed, $500 \pm 50 \mathrm{~mL}$ ). The antioxidant potential of four coconut varieties (green dwarf, yellow dwarf, red dwarf and yellow Malaysian) was compared with two industrialized coconut waters and the lyophilized water of the green dwarf variety. All varieties were effective in scavenging the DPPH radical $\left(\mathrm{IC}_{50}=73\right.$ $\mu \mathrm{L})$ and oxide nitric $(0.1 \mathrm{~mL}$ with an IP of $29.9 \%)$ as well as in inhibiting the in vitro production of thiobarbituric acid reactive substances ( $1 \mathrm{~mL}$ with an IP of 34.4\%), highlighting the antioxidant properties of the green dwarf which it is the most common used. In cell culture, the green dwarf water was efficient in protecting against oxidative damages induced by hydrogen peroxide.
\end{abstract}

Key words: Antioxidant activity, Ascorbic acid, Caffeic acid, Cocos nucifera, Polyphenols.

\section{INTRODUCTION}

Coconut palm, botanically known as Cocos nucifera, belongs to the family of Arecaceae (Palmae), animportantmemberofmonocotyledons. Brazil is the fourth largest coconut producer, accounting for $5 \%$ of world production. In addition, considering the consumption of coconut water, Brazil is the largest world producer, highlighting the Northeast region, with $85.6 \%$ of the national

Correspondence to: Humberto Reis Matos

E-mail: hrmatos10@hotmail.com culture production and a planted area, in 2002, of approximately 280,835 ha (Neto et al. 2007).

Around the world, coconut fruit products have been used in popular medicine for the treatment of various diseases, such as arthritis and diarrhea (Esquenazi et al. 2002). Studies carried out with the coconut husk fiber have proven its antiproliferative activity against lymphocytes (Kirszberg et al. 2003), and also determined its analgesic and antioxidant activities (Alviano et al. 2004). 
Coconut water $(\mathrm{CW})$, the liquid endosperm obtained from immature coconuts, in its natural form is a refreshing and nutritious beverage, widely consumed around the world due to its beneficial health properties (Pummer et al. 2001). Moreover, coconut water plays an important alternative role for oral rehydration and even for intravenous hydration of patients in remote regions (Campbell-Falck et al. 2000) in addition to protect against induction of myocardial infarction (Anurag and Rajamohan 2003). Antioxidant activities of polyphenolics derived from plants have claimed beneficial health functions for retarding aging and preventing cancer and cardiovascular diseases (Scalbert et al. 2005). Moreover, the presence of ascorbic acid in the natural CW was correlated with antioxidant properties (Mantena et al. 2003). A previous study confirmed the presence of caffeic acid in the coconut oil from the copra (Seneviratne and Dissanayake 2008). Chakraborty and Mitra (2008) proved the existence of chlorogenic, caffeoylshikimic and dicaffeoylquinic acids, three caffeic acid derivatives, in the methanolic extract of young, mature and old coconut mesocarp. Until the present moment, any study showed the identification and quantification of caffeic acid in coconut water (Cocos nucifera L). These findings highlight the need for studies to identify and quantify coconut water compounds with nutraceutical proprieties, specially the caffeic acid, since it is found in other parts of the coconut, such as the mesocarp which is in direct contact with $\mathrm{CW}$ indicating that this compound can be present in the coconut water.

The aims of this study were to: evaluate the $\mathrm{CW}$ antioxidant properties of four different varieties (green dwarf, yellow dwarf, red dwarf and yellow Malaysian), test the $\mathrm{CW}$ capacity to reduce the production of intracellular reactive oxygen species (ROS) in lung fibroblast (IMR-90) and establish a possible correlation between the observed antioxidant properties and the phenolic compounds present in $\mathrm{CW}$, ascorbic and caffeic acids, as others which were not identified as three caffeic and chlorogenic acids.

\section{MATERIALS AND METHODS}

COCONUT WATER

Ten young coconuts (3-4 months) of each different variety (green dwarf, yellow dwarf, red dwarf and yellow Malaysian) were collected from the Brazilian Agricultural Research Corporation (EMBRAPA) - Coastal Tablelands - Aracaju-SE/ Brazil. They were stored at $24^{\circ} \mathrm{C}$ for 24 hours, cleaned and opened only at the moment of the analysis. Boxes containing UHT (ultra high temperature) processed coconut water and bottles containing coconut water of the green dwarf variety were purchased from a local market.

\section{CHEMICALS}

2,2-Diphenyl-1-picrylhydrazyl (DPPH), 2',7'- dichlorfluorescein-diacetate (DCFH-DA) and 3,4- dihydroxycinnamic acid (caffeic acid) were bought from Sigma-Aldrich (St. Louis, MO, USA), 4,6- dihydroxy2-mercaptopyrimidine (thiobarbituric acid - TBA) was bought from Acros Organics (Geel, Belgium), trichloroacetic acid (TCA) was bought from Fluka (St. Louis, MO, USA), sodium nitroprusside and 2,4-dinitrophenylhydrazine from Merck (Darmstadt, Germany), L-threoascorbic acid (vitamin C) from Quimex (Chicago, USA), Folin solution from Deel (São Paulo, Brazil), sulphonilamide from Cromoline (São Paulo, Brazil), N-(1-naphthyl) ethylenediamine dihydrochloride from Acros Organics (Geel, Belgium) and quercetin $\left(3,3^{\prime}, 4,5^{\prime}, 7\right.$-pentahydroxyflavone dehydrate) from Aldrich (St. Louis, MO, USA). All the solvents for chromatographic purpose were HPLC grade, purchased from Merck (Darmstadt, Germany). All the other chemicals were purchased from Merck (Darmstadt, Germany).

SPECTROSCOPY

UV spectra were obtained with a Shimadzu UV1650PC (Shimadzu, Kyoto, Japan) scanning array dual beam spectrophotometer. One pair of $4 \mathrm{~mL}$ quartz cuvettes were used in the analysis. 
EXTRACTION AND QUANTIFICATION OF PHENOLIC

COMPOUNDS

Five green dwarf coconut water $(500 \pm 50 \mathrm{~mL})$ were lyophilized resulting in a $21.2 \pm 2.1 \mathrm{~g}$ of a highly hygroscopic mass, with a yield of $4.2 \% \pm$ $0.4 \%$. The lyophilized $(75 \mathrm{mg} / \mathrm{mL})$ was solubilized in methanol $50 \%$. The methanolic extract was centrifuged at $6,000 \mathrm{rpm}$ for $10 \mathrm{~min}$ for precipitating the debris. The supernatant was filtered at a 0.22 $\mu \mathrm{m}$ Durapore membrane and $150 \mu \mathrm{L}$ was analysis by high pressure liquid chromatography coupled to mass spectrometer (HPLC/MS/MS).

\section{HPLC-UV/VIS AND HPLC/MS/MS ANALYSIS}

The analysis was carried out using a Shimadzu HPLC apparatus coupled to UV-Vis detector SPD10AVP (Shimadzu, Kyoto, Japan) coupled in mass spectrometer Quattro II (Micromass, Manchester, UK) with source ionization eletronspray in positive mode $\left(\mathrm{ESP}^{+}\right)$. Phenomenex ${ }^{\mathrm{TM}} 5 \mu \mathrm{m}$ Luna C18 100A column (150 X $3.00 \mathrm{~mm} 5 \mu \mathrm{m}$ particular size) was used under $20^{\circ} \mathrm{C}$, flow $0.6 \mathrm{~mL} / \mathrm{min}$ and as mobile phase acetic acid $0.1 \%$ (A) and acetonitrila with acetic acid $0.1 \%$ (B) at gradient: $0 \mathrm{~min}-10 \%$ of $\mathrm{B}$; $40 \mathrm{~min}-90 \%$ of $\mathrm{B} ; 45 \mathrm{~min}-90 \%$ of $\mathrm{B} ; 47 \mathrm{~min}-10 \%$ of B; 60 min - Stop.

\section{ANTIOXIDANT ACTIVITY BY DPPH ASSAY}

The radical scavenging activity was determined by the spectrophotometric method based on the reduction of $\mathrm{MeOH}$ solution of 2,2-diphenyl-1picrylhydrazyl (DPPH) (Soler-Rivas et al. 2000). First, 100,500 and $1,000 \mu \mathrm{L}$ of each coconut water variety (green dwarf, yellow dwarf, red dwarf, yellow Malaysian), of the industrialized products and the green dwarf lyophilized $\mathrm{CW}$, solubilized in distilled water, were added to $2 \mathrm{~mL}$ of $\mathrm{MeOH}$ solution of DPPH $(90 \mu \mathrm{M})$. After an incubation period $\left(30 \mathrm{~min}\right.$ at $24^{\circ} \mathrm{C}$ ), the absorbance was read against a blank of $\mathrm{MeOH}$ at $515 \mathrm{~nm}$. The remaining $\mathrm{DPPH}$, measured after a certain time, inversely corresponded to the radical scavenging activity of the antioxidant. Finally, the inhibition percent (IP) and $\mathrm{IC}_{50}$ for each sample were calculated using an incubation time of 30 minutes. Quercetin, ascorbic and caffeic acids were used as positive controls.

\section{SCAVENGING OF NITRIC OXIDE in vitro}

In order to evaluate NO scavenging in vitro, it was used a nitroprusside solution (NPS) as generator of nitric oxide, as described by Green et al. (1982), in which this volatile radical spontaneously oxides to nitrite and then, reacts with sulfanilamide. The diazo compound formed reacts with the hydrochloride of $\mathrm{N}$-(1-naphthyl)-ethylenediamine, generating a pink chromophore. The NPS solution $5 \mathrm{mM}$ was diluted in phosphate buffered saline $(0.1 \mathrm{M}, \mathrm{pH} 7.0)$ and mixed at the proportion of $0.1,0.5$, and $1.0 \mathrm{~mL}$ of the analite: $4 \mathrm{~mL}$ of NPS with the analite of each coconut water variety, the industrialized water and lyophilized $\mathrm{CW}$ solubilized in distilled water and then incubated at $24^{\circ} \mathrm{C}$ for $150 \mathrm{~min}$. In parallel, a negative control experiment was conducted with water. In $30 \mathrm{~min}$ intervals, $0.5 \mathrm{~mL}$ of the mixture was mixed with $1 \mathrm{~mL}$ of water and $0.5 \mathrm{~mL}$ of Griess reagent (sulphanilamide $1 \%$ in $\mathrm{H}_{3} \mathrm{PO}_{4} 5 \%$ and $\mathrm{N}$-(1-naphthyl)-ethylenediamine dihydrochloride $0,1 \%$ ). The chromophore formed was measured at $546 \mathrm{~nm}$. Inhibition percent (IP) and $\mathrm{IC}_{50}$ for each sample were then calculated using the incubation time of $150 \mathrm{~min}$. Quercetin, ascorbic and caffeic acids were used as positive controls.

\section{DETERmination OF ANTIOXIDANT ACTIVITY With}

THIOBARBITURIC ACID (TBARS) in vitro

A modified TBARS assay was performed to measure the antioxidant potential capacity using egg yolk homogenate as a lipid rich medium (Hartwig et al. 1993). Briefly, $0.5 \mathrm{~mL}$ of $10 \%$ $(\mathrm{w} / \mathrm{v})$ egg yolk homogenate and $0.1,0.5$ and 1 $\mathrm{mL}$ of the sample solutions to be tested - each coconut water variety, the industrialized water (UHT processed and bottle) and the green dwarf lyophilized water solubilized in distilled water, 
prepared immediately before use - and $0.9 \mathrm{~mL}$ of $10 \mathrm{mM}$ of hydrogen peroxide in water were added to induce lipid peroxidation. After that, $1.5 \mathrm{~mL}$ of $20 \%$ acetic acid $(\mathrm{pH} 3.5)$ and $1.5 \mathrm{~mL}$ $1 \%(\mathrm{w} / \mathrm{v})$ thiobarbituric acid were subsequently added to the resulting mixture, vortexed and then heated at $90^{\circ} \mathrm{C}$ for $40 \mathrm{~min}$. After cooling, $3.0 \mathrm{~mL}$ of 1-butanol were added to each tube and then extensively vortexed and centrifuged at $1,800 \mathrm{~g}$ for $17 \mathrm{~min}$. The absorbance of the organic upper layer was measured using a spectrophotometer (UNICO - UV - 2100 spectrophotometer), set at $532 \mathrm{~nm}$. All the calculated values were based on the antioxidant inhibition percentage index (IP \%): IP\% $=(1$-At/ Ac) $\mathrm{x} 100$, where Ac is the absorbance value of the fully oxidized control and At is the absorbance of the test sample. The concentration of the reactive substances with tiobarbituric acid (TBARS) was calculated using the molar absorption coefficient of $157,000 / \mathrm{M} / \mathrm{cm}$. Quercetin, caffeic and ascorbic acids were used as positive controls.

\section{Determination of TOTAL PHENOLIC COMPOUNDS}

For this purpose, it was used the Folin-Ciocalteau method, with modifications (Singleton et al. 1999). The concentrations of total phenolics were calculated using the standard curve of gallic acid $(r=0.9987)$ and the results were expressed in milligrams of gallic acid equivalents (GAE) per liter.

\section{DETERMINATION OF GLUCOSE}

The aldo sacharids react with o-toluidine in glacial acetic acid medium producing a greenish coloration, as described by Hyvarinen and Nikkila (1962).

\section{DETERMINATION OF TOTAL LIPIDS}

The method used for determination of total lipids was described by Postma and Stroes (1968), which consists in the addition of concentrated sulfuric acid and vanillin solution $(5 \mathrm{mM})$ in phosphoric acid $(14.3 \mathrm{M})$, which in the presence of lipids resulting in a pink chromophore quantified in $537 \mathrm{~nm}$.

\section{DETERMINATION OF ASCORBIC ACID}

The method is based on the oxidation of ascorbic acid to dehydroascorbic acid and subsequent reaction with dinitrophenylhydrazine as described by Natelson (1957), with modifications. Briefly, $500 \mu \mathrm{L}$ of $\mathrm{CW}$ were added to tubes containing 200 $\mu \mathrm{L}$ of dinitrophenylhydrazine reagent (2 $\mathrm{g}$ of $2-4$ dinitrophenylhydrazine, $250 \mathrm{mg}$ of thiourea and $30 \mathrm{~g}$ of $\mathrm{CuSO}_{4} .5 \mathrm{H}_{2} \mathrm{O}$ dissolved in $100 \mathrm{~mL}$ of ice cold $\mathrm{H}_{2} \mathrm{SO}_{4} 9 \mathrm{~N}$ ) and placed in a water bath at $37^{\circ} \mathrm{C}$ for three hours, in order to test if this solution is stable for one week when kept under refrigeration. The solution was cooled in an ice bath, and 800 $\mu \mathrm{L}$ of cold $\mathrm{H}_{2} \mathrm{SO}_{4} 65 \%$ were added and rested for half an hour at room temperature. Finally, $500 \mu \mathrm{L}$ of $\mathrm{H}_{2} \mathrm{SO}_{4} 65 \%$ were added to a final volume of $2 \mathrm{~mL}$ to develop the red color which was measured at $520 \mathrm{~nm}$ in a spectrophotometer.

\section{Cell Culture}

Lung is one of the organs suffered from high concentration of oxygen and exposed high level of oxidative stress. So lung has good defense systems against oxidative stresses (Pryor et al. 1998, Kelly et al. 2003). To study the effect of caffeic acid on oxidative stress induced by hydrogen peroxide, we used lung fibroblasts (IMR-90). The cells IMR90 from the American Type Culture Collection were maintained at $37^{\circ} \mathrm{C}$ in an incubator with a humidified atmosphere of $5 \% \mathrm{CO}_{2}$ and cultured in RPMI containing 1\% non-essential amino acid, $10 \%$ heat-inactivated fetal calf serum, streptomycin $(100 \mathrm{~m} \mathrm{~g} / \mathrm{mL})$ and penicillin (100 units $/ \mathrm{mL})$.

\section{DCFH-DA (2',7'-DiCHLORFLUORESCEIN-DIACETATE) ASSAY}

The accumulation of intracellular ROS was measured using the fluorescent probe DCFH-DA (Cho et al. 2009) in lung fibroblast cells IMR-90. The DCFH-DA can be deacetylated in cells, where it can quantitatively react with intracellular oxidants $\left(\mathrm{H}_{2} \mathrm{O}_{2}\right)$ to be converted in its fluorescent product, 
the DCF, which is retained within cells and thus provides an index of oxidation in cell cytosol. The cells were cultured in a 24-well plate $(2 \mathrm{~mL}$ of DMEM), washed during $24 \mathrm{~h}$ and $20 \mu \mathrm{g} / \mathrm{mL}$ of DCFH-DA were loaded for $20 \mathrm{~min}$. After that, the cells were washed again and then, pre treated for 30 min with the green dwarf lyophilized water $(0.1 \%$ and $1 \%$ in $2 \mathrm{~mL}$ DMEM) or ascorbic acid $(25 \mu \mathrm{g} / \mathrm{mL})$ solubilized in water, washed and then exposed to $100 \mu \mathrm{M}$ of $\mathrm{H}_{2} \mathrm{O}_{2}$ for $5 \mathrm{~min}$. The cells were examined at $535 \mathrm{~nm}$ with excitation at 485 $\mathrm{nm}$ using a fluorescence spectrophotometer (Tecan Infinite M200 with XFluor 4 software, Austria).

\section{STATISTICAL ANALYSIS}

Values were expressed as the mean $\pm \mathrm{SD}$. For multiple comparisons, ANOVA, followed by Tukey's test, were applied. The $\mathrm{IC}_{50}$ values were obtained by non-linear regressions of concentration-response curves.

\section{RESULTS AND DISCUSSION}

Coconut water is widely used in tropical countries due to its flavor, nutritional properties and low cost. The results (Table I) demonstrate that, among all the varieties analyzed, glucose and total lipids showed a significant difference in all samples $(p<0.05)$, indicating that $\mathrm{CW}$ is a good source of caloric replacement of glucose and lipids, besides its other nutrients as amino acids and protein (DebMandal and Mandal 2011). Coconut has multifarious utility. The coconut water, the liquid endosperm, is an excellent natural drink with a caloric value of $17.4 / 100 \mathrm{~g}$. The wide applications of coconut water can be justified by its unique chemical composition of sugars, vitamins, minerals, amino acids and phytohormones (Young et al. 2009, DebMandal and Mandal 2011). The green dwarf variety exhibited the highest amount of total phenols and ascorbic acid (Table I). In addition, the green dwarf variety is the most consumed by the population; therefore it was selected for lyophilization. We made the choice of the concentration $(75 \mathrm{mg} / \mathrm{mL})$ to make a correlation between the green dwarf and the process of reconstitution of the lyophilized. The analysis of the lyophilized demonstrated that this process reduced by half the phenolic concentration, possibly due to the drag of low molecular weight phenols associated with the removal of water, however, the ascorbic acid concentration demonstrated no significative change in this process (Table I). In the UHT commercial samples, the phenolic content was very low possibly due to the use of high temperatures at sterilization which degrades compounds and ascorbic acid. Moreover, we consider the possibility that the acid ascorbic was added after the process.

TABLE I

Comparison of the constituents of four coconut varieties, industrialized products and lyophilized coconut water.

\begin{tabular}{ccccc}
\hline Samples & Glucose $(\mathbf{m g} / \mathbf{d L})$ & Total Lipids $(\mathbf{m g} / \mathbf{d L})$ & Ascorbic Acid $\boldsymbol{\mu g} / \mathbf{m L})$ & Total Phenolics $(\boldsymbol{\mu g} / \mathbf{m L})$ \\
\hline Green dwarf & $509.6 \pm 1.0^{\mathbf{b}}$ & $428.7 \pm 99.9^{\mathbf{b}}$ & $25.8 \pm 0.6$ & $99.4 \pm 12.4$ \\
Yellow dwarf & $192.0 \pm 2.9$ & $222.0 \pm 46.8$ & $20.1 \pm 3.3$ & $23.8 \pm 7.5^{\mathbf{a}}$ \\
Red dwarf & $610.1 \pm 60.2^{\mathbf{b}}$ & $233.1 \pm 17.4$ & $22.1 \pm 2.1$ & $18.4 \pm 3.6^{\mathbf{a}}$ \\
Yellow Malaysian & $807.2 \pm 69.1^{\mathbf{b}}$ & $392.7 \pm 62.3^{\mathbf{b}}$ & $11.3 \pm 2.5$ & $22.3 \pm 6.3^{\mathbf{a}}$ \\
UHT processed & $546.5 \pm 1.1^{\mathbf{b}}$ & $305.0 \pm 22.4$ & $13.9 \pm 3.9$ & $10.9 \pm 1.1^{\mathbf{a}}$ \\
Bottle & $548.8 \pm 1.0^{\mathbf{b}}$ & $300.4 \pm 24.7$ & $29.1 \pm 1.6$ & $13.0 \pm 3.1^{\mathbf{a}}$ \\
$\begin{array}{l}\text { Lyophilized } \\
(\mathbf{7 5} \mathbf{~ m g / m L ) ~}\end{array}$ & $670.1 \pm 48.6^{\mathbf{b}}$ & $307.4 \pm 13.7$ & $21.8 \pm 0.8$ & $48.8 \pm 10.7^{\mathbf{a}}$ \\
\hline
\end{tabular}

Data are means $\pm \mathrm{SD}(\mathrm{n}=10)$. (a) These data are significantly different when compared with the Green dwarf group ( $<<0.05$ ). (b) These data are significantly different when compared with the Yellow dwarf group $(\mathrm{p}<0.05)$. For multiple comparisons, ANOVA, followed by Tukey's test, were applied. 
The results (Table II) showed that all varieties were able to scavenge the free radical DPPH and the green dwarf variety showed the best antioxidant activity with an $\mathrm{IC}_{50}$ of $150 \mu \mathrm{g} / \mathrm{mL}$ DPPH. In the inhibition analysis of nitrite formation from NPS 5 $\mathrm{mM}$ solution, the red dwarf variety was highlighted for its relatively high IP value of $57.7 \%$, followed by the yellow dwarf $(\mathrm{IP}=38.4 \%)$ and the yellow Malaysian ( $\mathrm{IP}=36.5 \%)$. Therefore, this activity provide the basis of the popular anti-inflammatory utilization of the red dwarf, since the action of endogenous nitric oxide (NO) is the modulation of the inflammatory state, acting on the platelet aggregation and vasodilatation (Saha and Pahan 2006). As shown by a previous study (Maia et al. 2010), natural substances such as gallic acid have an ability to scavenge nitric oxide. In high concentrations NO can react with superoxide anion and produce potentially harmful peroxynitrite (Peluffo and Radi 2007), which is involved in the genesis of several disorders including induced lipid peroxidation, membrane destabilization (Virág et al. 2003), oxidation, protein nitration, and DNA damage (Ippoushi et al. 2009). Thus, substances able to scavenge NO may inhibit the development of these disorders. In previous studies, we proved that natural substances such as lycopene can protect cultured mammalian cells against biomolecular damage induced by Fe-NTA/ascorbate treatment (Matos et al. 2000), showing the in vivo protective effect of lycopene against iron-induced DNA, membrane damage and histopathologic changes in liver of rats (Matos et al. 2001) as well as that both lycopene and B-carotene protected in vivo damage of iron-induced oxidative stress in rat prostate (Matos et al. 2006).

As a benchmark for the analysis, we used pure substances such as quercetin and ascorbic acid in the concentrations of total phenols and ascorbic acid found in the green dwarf water. We also used caffeic acid, whose dose was established from the correlation with the concentration of chlorogenic acid, a derivative of caffeic acid formed from association with quinic acid (Soares 2002) and found in the mesocarp of the same variety (Chakraborty and Mitra 2008). Of these, the ascorbic acid showed the highest antioxidant activity on DPPH radical scavenging and in inhibiting the formation of nitrite, while the caffeic acid, at the concentration used, recorded an IP of only $3.8 \%$ for DPPH, but it was not able to reach the $\mathrm{IC}_{50}$ for in vitro $\mathrm{NO}$ analysis (Table II).

Regarding the TBARS determination, the green dwarf variety demonstrated the best antioxidant activity with $34.4 \%$ IP, followed by the red dwarf $(\mathrm{IP}=31.4 \%)$. The results obtained from the analysis of the lyophilized water demonstrated that even though it retained the concentration of ascorbic acid and phenolic content of half the original sample (green dwarf water), it was not able to inhibit the formation of TBARS, therefore causing a significant increase $(p<0.05)$ in the same, when compared to the negative control. The yellow Malaysian and the lyophilized water showed low antioxidant activity. Among the pure compounds tested, the caffeic acid showed the best activity with $28.2 \%$ IP, close to the BHT result, a known standard antioxidant (Figure 1). The measured percentage of TBARS inhibition showed a high correlation with the total phenols levels (red dwarf: $r=1.000$; green dwarf: $r=0.988$; yellow dwarf: $r=0.988$; yellow Malaysian: $r=0.976$; UHT: $r=0.956$; Bottle: $r=0.993$; Lyophilized: $r=0.866$ ). Therefore, the total phenols levels may be responsible for the antioxidant activity against the inhibition of formation of TBARS.

The green dwarf variety was selected for chemical characterization by HPLC and assessment of its antioxidant potential in cultured lung fibroblasts (IMR-90) as it is the most widely consumed and showed the best results in the antioxidant screening. Regarding the cell culture, fibroblasts were chosen taking in account that they usually exist in the lung, which is a highly vascularized organ with a large positive oxygen pressure, creating an environment adequate to oxidative reactions. 
TABLE II

Inhibitory effect of different varieties of coconut water in nitrite production and in scavenging the radical DPPH.

\begin{tabular}{|c|c|c|c|c|c|}
\hline \multirow{2}{*}{ Samples } & \multicolumn{3}{|c|}{ NO } & \multicolumn{2}{|r|}{ DPPH } \\
\hline & IP (\%) & $\mathrm{IC}_{50}(\mu \mathrm{g} / \mathrm{mL} \mathrm{NPS})$ & Nitrite concentration $(\mu \mathrm{M})$ & IP $(\%)$ & $\mathrm{IC}_{50}(\mu \mathrm{g} / \mathrm{mL} \mathrm{DPPH})$ \\
\hline Nitroprusside $5 \mathrm{mM}$ & $\begin{array}{ll}--- \\
---\end{array}$ & $\begin{array}{ll}--- \\
---\end{array}$ & $26.8 \pm 1.5^{\mathrm{b}}$ & $\begin{array}{ll}--- \\
---\end{array}$ & $\begin{array}{ll}--- \\
---\end{array}$ \\
\hline Caffeic acid $(30 \mu \mathrm{g} / \mathrm{mL})$ & 18.6 & ND & $21.8 \pm 0.7^{\mathrm{b}}$ & 3.8 & 3.5 \\
\hline Ascorbic acid $(25 \mu \mathrm{g} / \mathrm{mL})$ & 57.0 & 20.3 & $11.5 \pm 1.7^{\mathrm{a}}$ & 28.1 & 5.5 \\
\hline Quercetin $(100 \mu \mathrm{g} / \mathrm{mL})$ & 40.5 & 697.5 & $15.4 \pm 1.5^{\mathrm{a}}$ & 8.1 & 25.4 \\
\hline Green dwarf $(0.1 \mathrm{~mL} / \mathrm{mL})$ & 29.9 & 219.7 & $18.8 \pm 2.0^{\mathrm{ab}}$ & 38.3 & 150.0 \\
\hline Yellow dwarf $(0.1 \mathrm{~mL} / \mathrm{mL})$ & 38.4 & 638.1 & $16.5 \pm 2.4^{\mathrm{a}}$ & 38.1 & 186.0 \\
\hline Red dwarf $(0.1 \mathrm{~mL} / \mathrm{mL})$ & 57.7 & 25.5 & $10.2 \pm 1.3^{\mathrm{a}}$ & 22.7 & 194.9 \\
\hline Yellow Malaysian $(0.1 \mathrm{~mL} / \mathrm{mL})$ & 36.5 & 81.7 & $17.0 \pm 4.4^{\mathrm{a}}$ & 3.6 & 390.2 \\
\hline UHT processed $(0.1 \mathrm{~mL} / \mathrm{mL})$ & 52.3 & 14.5 & $12.8 \pm 1.8^{\mathrm{a}}$ & 51.3 & 30.2 \\
\hline Bottle $(0.1 \mathrm{~mL} / \mathrm{mL})$ & 19.7 & 234.3 & $21.5 \pm 2.0^{\mathrm{b}}$ & 14.5 & 156.0 \\
\hline Lyophilized (75 mg/mL) & 57.3 & 175.9 & $11.4 \pm 2.2^{\mathrm{a}}$ & 20.2 & 549.2 \\
\hline
\end{tabular}

$\mathrm{ND}$ - non-detected. Data are means $\pm \mathrm{SD}(\mathrm{n}=10)$. (a) These data are significantly different when compared with the nitroprusside group $(p<0.05)$. (b) These data are significantly different when compared with the ascorbic acid group ( $<<0.05)$. For multiple comparisons, ANOVA, followed by Tukey's test, were applied.

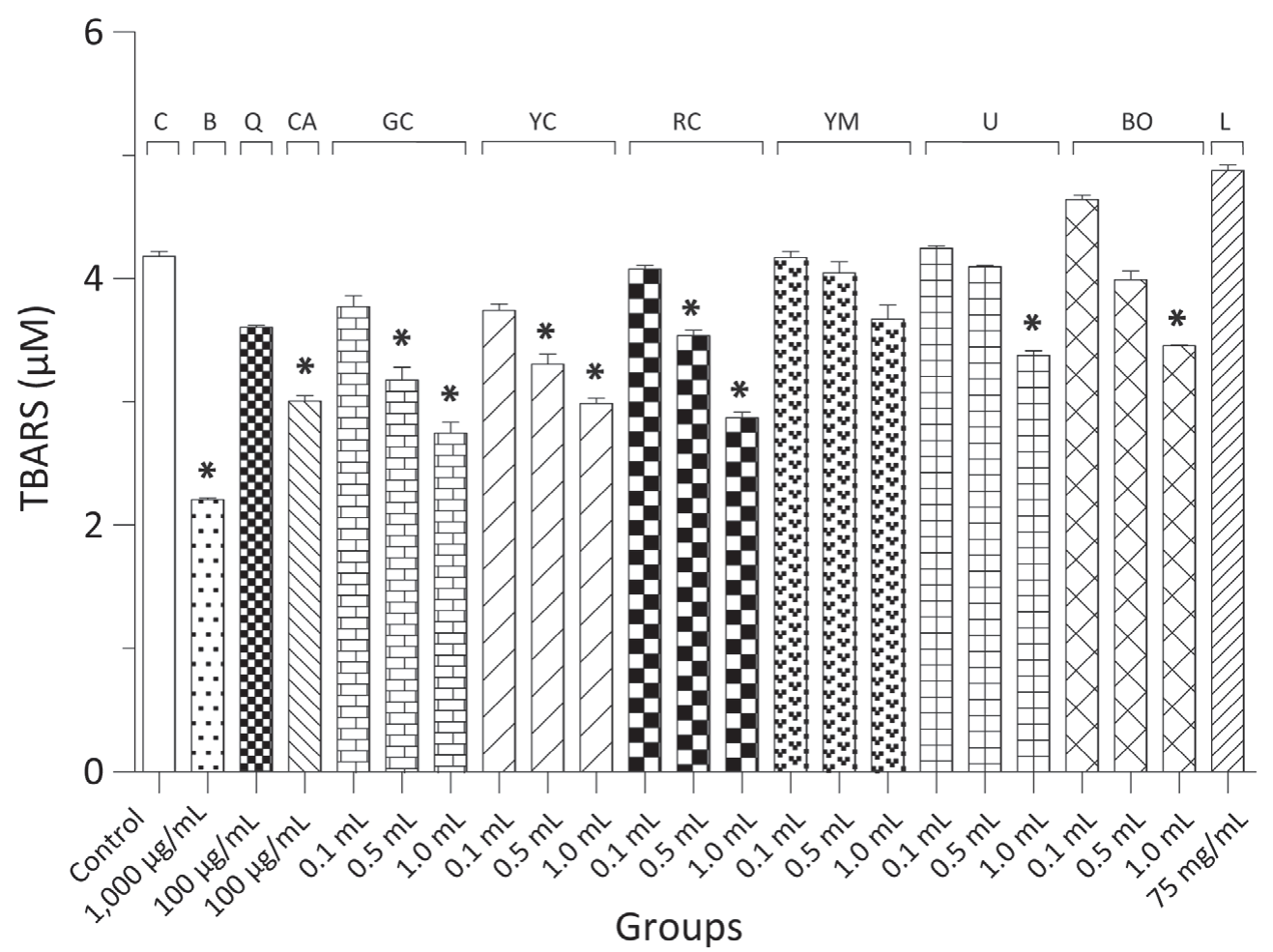

Figure 1 - Effects of four different coconut water varieties, industrialized and the lyophilized water in preventing TBARS formation. (C) Negative control; (B) BHT; (Q) Quercetin; (CA) Caffeic acid; (GC) Green dwarf; (YC) Yellow dwarf; (RC) Red dwarf; (YM) Yellow Malaysian; (U) UHT processed; (BO) Bottle; (L) Lyophilized. Data are means \pm SD $(n=10)$. (*) These data are significantly different when compared with the negative control $(\mathrm{p}<0.05)$. For multiple comparisons, ANOVA, followed by Tukey's test, were applied. 
The results obtained in evaluating the antioxidant potential in the cytosol of cultured fibroblasts $\left(1 \times 10^{6}\right.$ per plate) confirmed that there was a significant difference $(\mathrm{p}<0.05)$ among all groups when compared with the $\mathrm{H}_{2} \mathrm{O}_{2}$ group, showing that the pretreatment with coconut water was able to reduce the concentration of intracellular ROS when compared to the ascorbic acid (Figure 2). In a previous study it was demonstrated that treatment of WI-38 lung fibroblast cells with caffeic acid (0.5, 5 and $5 \mu \mathrm{M}$ ) reduced the fluorescence intensity by $\mathrm{H}_{2} \mathrm{O}_{2}$ treatment, reflecting a reduction of ROS generation (Kang et al. 2006). Fonseca et al. (2009) confirmed the presence of long chain fatty acids such as the palmitic and oleic acids in green dwarf water, as well as the possibility that $\beta$-oxidation, occurring at the peroxisome level, generated a slight rise of peroxide, which is responsible by increasing intracellular ROS in CW 1\% group. About the ascorbic acid treated group, because of its high concentration in the cytosol of cells, there is the possibility that ascorbic acid interfered in the method, since ascorbate may be a reducing agent, such as it occurs in yeast (Monteiro et al. 2007).



Figure 2 - Accumulation of intracellular ROS expressed in cytosolic oxidation percentage. The samples were pre-incubated with Coconut Water $(\mathrm{CW})$ at 0.1 and $1 \%$ of final concentration or Ascorbic Acid (Asc. Ac.) $25 \mu \mathrm{g} / \mathrm{mL}$ at the well plate, washed and exposed to the same equitoxic concentrations of $\mathrm{H}_{2} \mathrm{O}_{2}(100 \mu \mathrm{M})$ for 5 minutes and measured after 20 minutes of DCFH-DA incubation. A negative control group using distilled water (Control) was performed.Data are means $\pm \operatorname{SD}(n=3) .(*)$ These data are significantly different when compared with the Control group $(\mathrm{p}<0.05)$. $(* *)$ These data are significantly different when compared with the $\mathrm{H}_{2} \mathrm{O}_{2}$ group $(\mathrm{p}<0.05)$. For multiple comparisons, ANOVA, followed by Tukey's test, were applied.

Before that works showed the presence of chlorogenic acid, a derivative of caffeic acid in the mesorcarp of Cocos nucifera (Chakraborty and Mitra 2008). Considering that this portion is in close contact with the coconut water, we were to investigate if caffeic acid is a compound of coconut water. First, we development a sensitive methodology by HPLC/MS/MS in $\mathrm{ESP}^{+}$(electron 
spray ionization in positive mode) to quantification of the caffeic acid. For this method, as showed in profile fragmentation of the Figure 3, the caffeic acid (standard Sigma) forming majority $\mathrm{m} / \mathrm{z}=181 \rightarrow 163$ at a retention time $(\mathrm{RT})$ of the 8.2 minutes (dates no showed). In Figure 4, we can see that when this transition $(\mathrm{m} / \mathrm{z}=181 \rightarrow 163)$ is monitored in the LCW $(150 \mu \mathrm{L}$ of a solution 75 $\mathrm{mg} / \mathrm{L}$ in $\mathrm{MeOH} 50 \%$ ) we found a pick in same RT of the caffeic acid. For this results, we can prove that caffeic acid is present in coconut water in a concentration of $1.078 \pm 0.013 \mu \mathrm{g} / \mathrm{mL}$.

This study highlights the importance of coconut water as a nutritious food and its antioxidant properties. All varieties showed good antioxidant potential, highlighting the green dwarf which showed the best results in scavenging

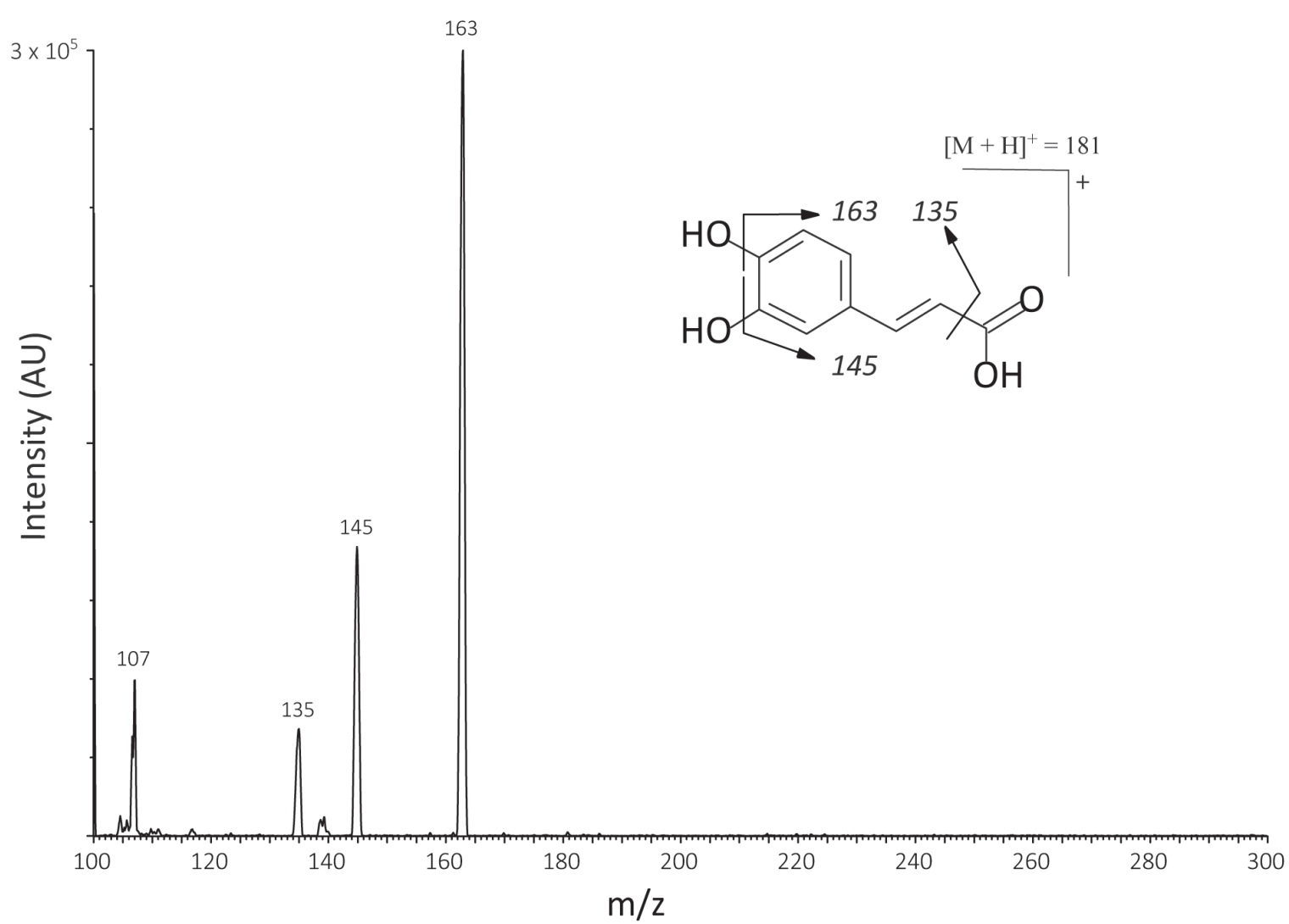

Figure 3 - Profile fragmentation of standard caffeic acid. The analysis by mass spectrometry Quattro II (Micromass, Manchester, UK) with source ionization $\mathrm{ESP}^{+}$monitoring of the $\mathrm{m} / \mathrm{z}=181 \rightarrow 163$. Parameters of the mass spectrometer: Source temperature $100{ }^{\circ} \mathrm{C}$; Desolvation temperature $150{ }^{\circ} \mathrm{C}$; Capillary voltage $2.5 \mathrm{kV}$; Cone voltage $25 \mathrm{~V}$, Collision energy $15 \mathrm{eV}$.
DPPH radical and in protecting lipids against the formation of TBARS, as well as recording the highest levels of total phenols and vitamin C. We also observed that the industrialized processes, such as UHT and lyophilization drastically reduced the coconut water contents and, therefore, its therapeutic properties. Moreover, in cell culture the green dwarf water was effective in protecting fibroblasts against damage induced by hydrogen peroxide. Finally, the chromatographic analysis confirmed the presence of the caffeic acid $(1.078 \pm 0.013 \mu \mathrm{g} / \mathrm{mL}$ or $539 \mu \mathrm{g}$ for units of coconut consumed, $500 \pm 50 \mathrm{~mL}$ ), which proved to be effective in inhibiting the in vitro TBARS formation. Although we achieved our goals, there is still a huge gap in the determination of coconut water constituents. 

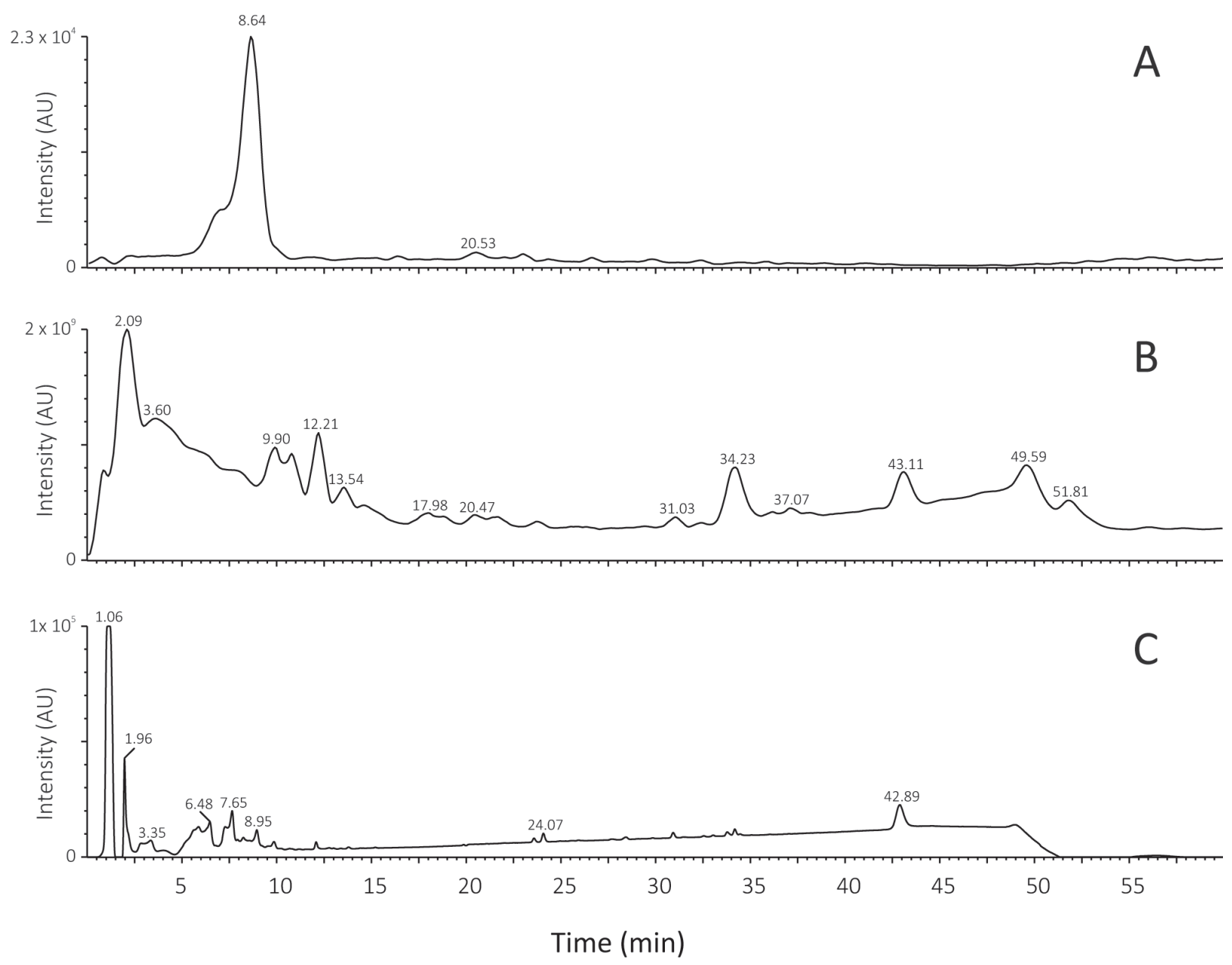

Figure 4 - HPLC/MS/MS analysis of the lyophilized coconut water (LCW). It was analyzed $150 \mu \mathrm{L}$ of a methanolic solution (MeOH 50\%) $75 \mathrm{mg} / \mathrm{mL}$ in column Luna C18 $150 \times 3 \mathrm{~mm} 5 \mu \mathrm{m}$ particular size, under $20{ }^{\circ} \mathrm{C}$, flow $0.6 \mathrm{~mL} / \mathrm{min}$ and using as mobile phase (A) Acetic acid $0,1 \%$ and (B) ACN with $0,1 \%$ acetic acid. The total flow $(0.6 \mathrm{~mL} / \mathrm{min})$ was divided by splitter, going to mass spectrometry $0.135 \mathrm{~mL} / \mathrm{min}$. A - monitoring of the $\mathrm{m} / \mathrm{z}=181 \rightarrow 163$; B - Total scan to $\mathrm{ESP}^{+}$; C - chromatogram in $320 \mathrm{~nm}$. Parameters of the mass spectrometer: Source temperature $100{ }^{\circ} \mathrm{C}$; Desolvation temperature $150{ }^{\circ} \mathrm{C}$; Capillary voltage $2.5 \mathrm{kV}$; Cone voltage $25 \mathrm{~V}$, Collision energy $15 \mathrm{eV}$.

\section{ACKNOWLEDGMENTS}

We thank Wilson Aragão, of the EMBRAPA - Coastal Tablelands, for kindly providing the coconut samples for analysis, $\mathrm{Dr}^{\mathrm{a}}$ Camila C. M. Garcia and Msc. José Pedro F. Angeli for supporting the DCFH-DA assay. This work received technical and financial support of Conselho Nacional de Desenvolvimento Científico e Tecnológico (CNPq) and Instituto Nacional de Ciência e Tecnologia de Processos Redox em Biomedicina (INCT REDOXOMA).

\section{RESUMO}

A água de coco contém várias substâncias não caracterizadas e é amplamente utilizada na alimentação humana. Neste estudo, foram detectados e quantificados ácido ascórbico e ácido cafeico e polifenóis totais em diversas variedades de coco, e usando HPLC/MS/ MS $(25,8 \pm 0,6 \mu \mathrm{g} / \mathrm{mL}, 1,078 \pm 0,013 \mu \mathrm{g} / \mathrm{mL}$ and 99,7 $\mu \mathrm{g} / \mathrm{mL}$, respectivamente, em água de coco do anão verde, ou $10 \mathrm{mg}, 539 \mu \mathrm{g}$ e $39,8 \mathrm{mg}$ por unidades de coco consumido, $500 \pm 50 \mathrm{~mL}$ ). O potencial antioxidante da água de coco das quatro variedades de 
coqueiro (anão verde, anão amarelo, anão vermelho e amarelo malasiano) foi comparada com água de coco industrializada e água liofilizada da variedade anão verde. Todas as variedades foram eficazes - com destaque para as propriedades antioxidantes do anão verde, uma vez que é o mais comum usado - no sequestro do radical DPPH $\left(\mathrm{IC}_{50}=73 \mu \mathrm{L}\right)$, óxido nítrico $(0,1 \mathrm{~mL}$ com IP de $29,9 \%$ e e inibindo a produção de espécies reativas com o ácido tiobarbitúrico ( $1 \mathrm{~mL}$ com IP de 34,4\%) in vitro. Em cultura de células, a água de coco da variedade anão verde foi eficiente na proteção contra danos oxidativos induzidos por peróxido de hidrogênio.

Palavras-chave: Atividade antioxidante, ácido ascórbico, ácido cafeico, Cocos nucifera, polifenóis.

\section{REFERENCES}

ALVIANO DS, RODRIGUES KF, LEITÃo SG, RODRIGUES ML, Matheus ME, Fernandes PD, ANTONIOlli AR AND ALVIANO CS. 2004. Antinociceptive and free radical scavenging activities of Cocos nucifera L. (Palmae) husk fiber aqueous extract. J Ethnopharmacol 92: 269-273.

ANURAG P AND RAJAMOHAN T. 2003. Cardioprotective effect of tender coconut water in experimental myocardial infarction. Plant Food Hum Nutr 58: 1-12.

CAmpbell-Falck D, Thomas T, Falck TM, Tutuo N AND CLEM K. 2000. The intravenous use of coconut water. Am J Emerg Med 18: 108-111.

Chakraborty M AND Mitra A. 2008. The antioxidant and antimicrobial properties of the methanolic extract from Cocos nucifera mesocarp. Food Chem 107: 994-999.

Cho ES, Jang YJ, Kang NJ, Hwang MK, Kim YT, LeE KW AND LEE HJ. 2009. Cocoa procyanidins attenuate 4-hydroxynonenal-induced apoptosis of PC12 cells by directly inhibiting mitogen-activated protein kinase kinase 4 activity. Free Radical Bio Med 46: 1319-1327.

DebMandal M and Mandal S. 2011. Coconut (Cocos nucifera $\mathrm{L}$.: Arecaceae): In health promotion and disease prevention. Asian Pac J Trop Med, p. 241-247.

EsquenaZI D, WigG MD, Miranda MMFS, Rodrigues HM, Tostes JB, Rozental S, Silva AJR and ALviano CS. 2002. Antimicrobial and antiviral activities of polyphenolics from Cocos nucifera Linn (Palmae) husk fiber extract. Res Microbiol 153: 647-652.

FonseCA AM, BizerRa AMC, SOUZA JSN, Monte FJQ, Oliveira MCF, Mattos MC, CoRdell GA, BRAZ-Filho R AND LEMOS TLG. 2009. Constituents and antioxidant activity of two varieties of coconut water (Cocos nucifera L.). Braz J Pharmacognosy 19: 193-198.

GREEN LC, WAGNER DA AND GLOGOWSKI J. 1982. Analysis of nitrate, nitrite, and $[15 \mathrm{~N}]$ nitrate in biological fluids. Anal Biochem 126: 131-138.
Hartwig A, KLYSZCZ-NASKo H, SChLEPEgRell R AND BEYERSMANN D. 1993. Cellular damage by ferric nitrilotriacetate and ferric citrate in V79 cells-in ferrelationship between lipid-peroxidation, DNA stand breaks and sister chromatid exchanges. Carcinogenesis 14: 107-112.

HYVARINEN A AND NIKKILAEA. 1962. Specific determination of blood glucose with o-toluidine. Clin Chim Acta 7: 140-143.

IPPOUSHI K, TAKeUCHI A AND AZUMA K. 2009. Prevention of peroxynitrite-induced oxidation and nitration reactions by ellagic acid. Food Chem 112: 185-188.

KANG KA ET AL. 2006. Caffeic acid protects hydrogen peroxide induced cell damage in wi-38 human lung fibroblast cells. Biol Pharm Bul 29: 1820-1824.

Kelly FJ, Dunster C AND Mudway I. 2003. Air pollution and the elderly: oxidant/antioxidant issues worth consideration. Eur Respir J 21: 70-75.

Kirszberg C, Esquenazi D, Alviano CS and RumuaneK VM. 2003. The effect of a catechin-rich extract of Cocos nucifera on lymphocytes proliferation. Phytother Res 17: 1054-1058.

Maia RM, MOURA CWN, Bispo V, SANTOS JLA, SANTANA RS AND MATOS HR. 2010. Avaliação do sequestro do óxido nítrico (NO) pelo extrato metanólico da alga Bryothamnion triquetrum (Gmelin) Howe. Braz J Pharmacognosy 20: 489-493.

MANTENA SK, BADDURI SR, SiRIPURAPU KB AND UNNIKRISHNAN MK. 2003. In vitro evaluation of antioxidant properties of Cocos nucifera Linn. water. Nahrung 47: 126-131.

MATOS HR, CAPELOZZI VL AND GOMES OF. 2001. Lycopene Inhibits DNA Damage and Liver Necrosis in Rats Treated with Ferric Nitrilotriacetate. Arch Biochem Biophy 396: 171-177.

Matos HR, Di Mascio P and Medeiros MHG. 2000. Protective Effect of Lycopene on Lipid Peroxidation and Oxidative DNA Damage in Cell Culture. Arch Biochem Biophy 383: 56-59.

Matos HR, Marques SA, Gomes OF, Silva Aa, Heimann JC, Di Mascio P AND MedeIros MHG. 2006. Lycopene and $\beta$-carotene protect in vivo iron-induced oxidative stress damage in rat prostate. J Med Bio Res 39: 203-210.

Monteiro G, Horta BB, Pimenta DC, Augusto O and NETTO LES. 2007. Reduction of 1-Cys peroxiredoxins by ascorbate changes the thiol-specific antioxidant paradigm, revealing another function of vitamin C. P Natl Acad Sci USA 104: 4886-4891.

NATELSON S. 1957. Microtechniques of clinical chemistry for the routine laboratory, $2^{\text {nd }}$ ed., Springfield: Thomas, $332 \mathrm{p}$.

Neto MF, Holanda JS, Folegatti MV, GHeYi HR, Pereira WE AND CAVALCANTE LF. 2007. Qualidade do fruto do coqueiro anão verde em função de nitrogênio e potássio na fertirrigação. Rev Bras Eng Agríc Amb 11: 453-458.

Peluffo Gand TAdi R. 2007. Biochemistry of protein tyrosine nitration in cardiovascular pathology. Cardiovascular Res 7: 291-302. 
Postma T AND STROES JAP. 1968. Lipid screening in clinical chemistry. Clin Chim Acta 22: 569-578.

Pryor WA, Stone K, ZANG LY AND Bermudez E. 1998. Fractionation of aqueous cigarette tar extracts: Fractions that contain the tar radical cause DNA damage. Chem Res Toxicol 11: 441-448.

Pummer S, Heil P, Maleck W and Petroianu G. 2001. Influence of coconut water on homeostasis. Am J Emerg Med 19: 287.

SAHA RN AND PAHAN K. 2006. Signals for the induction of nitric oxide synthase in astrocytes. Neurochem Int 49: 154-163.

SCALBERT A, JOHnson IT AND SALTMARsh M. 2005. Polyphenols: Antioxidants and beyond. Am J Clin Nutr 81: 215-217.

SENEVIRATNE KN AND DisSANAYAKE DMS. 2008. Variation of phenolic content in coconut oil extracted by two conventional methods. Int J Food Sci Tech 43: 597-602.
SINGLETON VL, ORTHOFER R AND LAMUELA-RAVENTÓS RM. 1999. Analysis of total phenols and other oxidation substrates and antioxidants by means of Folin-Ciocalteu reagent. In: L. Packer, Editor, Methods in Enzymology 299: 152-178.

SOARES SE. 2002. Phenolic acids as antioxidants. Rev Nutr 15: 71-81.

SOLER-RIVAS C, ESPÍN JC AND WICHERS HJ. 2000. An easy and fast test to compare total free radical scavenger capacity of foodstuffs. Phytochem Analysis 11: 330-338.

Virág L, Szabó E, Gergely P AND SZABÓ C. 2003. Peroxynitrite-induced cytotoxicity: mechanism and opportunities for intervention. Toxicol Lett 140-141: 113-124.

Young JWH, GE L, NG YF AND TAN SN. 2009. The Chemical Composition and Biological Properties of Coconut (Cocos nucifera L.) Water. Molecules 14: 5144-5164. 